\title{
PRIME Partnerships in International Medical Education - Restoring a Christian ethos to medical education worldwide
}

\author{
Huw Morgan ${ }^{a}$ \\ ${ }^{a}$ Retired GP/Medical missionary, Medical Educator, Staff Tutor and Executive member of PRIME, Emeritus \\ Director of GP training, Bristol, UK
}

\begin{abstract}
Modern medicine has developed from an essentially Christian world-view and in Western countries has been greatly influenced by the Christian tradition of hospitality and caring for the sick. However, during the $20^{\text {th }}$ century, medical education became increasingly secularised and focussed on the bio-physical model of disease, losing sight of a holistic view of the person that includes awareness of a spiritual dimension. Former Communist countries in particular have little recent tradition of caring, and medical education there tends to be characterised by poor role-models and out-dated didactic teaching. In the resource poor countries of the global South there are many Christian hospitals and clinics but often a lack of experienced medical teachers. Partnerships in International Medical Education (PRIME)'s vision and mission is to support health-care education worldwide to restore a Christian-based holistic approach to patients, and act as a resource where needed, tailoring medical educational programmes to meet the needs of overseas partners (or colleagues in the NHS). Using interactive leaner-centred and problembased educational methods, PRIME tutors (all experienced and qualified Christian medical educators) seek to model patient-centred care by using learner-centred teaching, valuing each person as a bearer of the image of God. Most of PRIME's teaching involves the doctor-patient relationship, communication skills, compassion, ethics and professionalism, often based around particular clinical scenarios to suit the learners. Small teams of voluntary tutors visiting partner institutions and colleagues for a few weeks a year can have a surprisingly large impact, as those grasping the vision become advocates for positive change in their own situations. Training of trainers and teachers in learner-centred, androgogic methodology to build capacity and sustainability is also a major part of the work.
\end{abstract}

\section{Introduction}

PRIME, http://www.prime-international.org is a Christian medical education charity, an international network of Christian healthcare professionals who are involved in teaching their discipline. In this paper, I will briefly outline the historical context of PRIME's work and the challenges and opportunities we face in contemporary medical education around the world and then describe how PRIME is working to meet them. ("Medical" here is used to include nursing and professions allied to medicine.)

Nov 2016. Christian Journal for Global Health, 3(2): 134-139. 


\section{Historical Context}

Modern medicine and medical teaching have developed in the Western world, influenced by both the Christian tradition of hospitality pioneered by the European monasteries ${ }^{1}$, and the Judao-Christian value system that has historically underpinned the major institutions of our society (Government, Law, Education, Commerce, etc.). ${ }^{2}$ This is particularly the case in Western and Northern European countries that experienced the Protestant Reformation in the $16^{\text {th }}$ century. In addition, it can be argued that the scientific advances that have led to the development and success of modern medicine stem from the Reformation's effect on thought that saw the investigation of the material world as a legitimate and necessary enterprise in understanding God's creation ("Thinking God's thoughts after Him" Johannes Kepler, 1599). ${ }^{3}$

The remarkable advances in medicine in the $19^{\text {th }}$ and $20^{\text {th }}$ centuries such as greatly improved public health, the development of surgery and anaesthesia, immunisation, antibiotics, treatment for hormone deficiencies (insulin, thyroxine), effective treatment for many chronic diseases and for mental illnesses all flowed from this, and Christian doctors were involved in many of these advances. In addition, the missionary movement that started in the $19^{\text {th }}$ century resulted in mission hospitals and community health programmes being established in many remote areas in the majority of the world, bringing the advantages of modern medicine delivered with a Christian ethos to the poor and marginalized in many developing countries. $^{4}$

\section{The Challenge We Face}

However, the Reformation also paved the way for the Enlightenment, which gradually eroded belief in God from the scientific and public arenas through the 17th century and following, so that the moral and spiritual framework that had guided the development of modern science and medicine was lost. ${ }^{5}$ The subsequent atheistic and reductionist approach presupposed that the material world was all that existed and that everything could be understood in terms of its molecular structure. Thus Francis Crick, one of the discoverers of the structure of DNA, famously said, "You, your joys, sorrows, memories and ambitions are in fact no more than the behaviour of a vast assembly of nerve cells and their associated molecules." 6 This perspective has tended to dehumanise the practice and teaching of medicine, leading to the loss of understanding that patients, students, and doctors are all human beings made in God's image. There has been too much emphasis on narrow scientific knowledge, abusive teaching methodologies inappropriate for a caring profession, and lack of a whole person perspective and compassion in teaching and practice. ${ }^{7}$ So the realities of medical practice in the world today include the following:

- Gross inequalities in access to health care within and between nations

- Poor governmental management of health care systems

- Loss of humanity and compassion by health care workers

- Failure to respect human life from conception to natural death

- Medical practice increasingly divorced from an ethical framework

- The threats of unregulated germ-line gene therapy and selective embryo screening

- Lack of acknowledgment of a spiritual perspective in human suffering

- Excessive emphasis on science and systems in the teaching and practice of medicine

- Gradual loss of idealism and growth of cynicism amongst students and young doctors and nurses ${ }^{8}$

In the former communist countries, there tends to be little recent tradition or history of a caring approach to patient-care. There are also frequently only limited, out-date didactic teaching and text books with little exposure to real patients or opportunities for students to develop problem solving skills. There are also often poor rolemodels and widespread corruption in health care and its teaching, where bribes are necessary to be seen or taught by a doctor and to pass examinations. ${ }^{9}$ In the resource poor countries of 
the global South (such as in Africa, Asia, and South America) the too few doctors and healthcare professionals often have to work in isolation with little opportunity for continuing professional development and so lack appropriate training and skills. There is an understandable tendency for doctors and nurses to immigrate to richer countries to work, further adding to the resource problem. ${ }^{10}$

\section{A Door of Opportunity}

There is light dawning, however! The "Modern" era is ending and "Post-Modernism" is challenging the closed scientific world-view of Modernity. People are dissatisfied with dehumanising medical treatments (successful as they may be) and are searching for alternatives. ${ }^{11}$ Spirituality and concern for the whole person are making a comeback. Many medical schools are teaching communication skills and using humanities to aid reflection on the human condition. In our now electronically interconnected world, there is more awareness of the global inequalities in health-care and a desire to redress them. The World Health Organisation (WHO) reports:

Until recently the health professions have largely followed a medical model, which seeks to treat patients by focusing on medicines and surgery, and gives less importance to beliefs and to faith in healing, in the physician and in the doctorpatient relationship. This reductionist or mechanistic view of patients is no longer satisfactory. Patients and physicians have begun to realise the value of elements such as faith, hope, and compassion in the healing process. ${ }^{12}$

So as this new millennium began, Christians had a great opportunity to reclaim the teaching of Medicine as a spiritual and ethical practice. We need to practice and teach in a way that demonstrates respect for our patients and learners as people made in God's image. We must also ensure our teaching embodies the concept of Whole Person Care for our patients, including a spiritual perspective, alongside evidence-based scientific truth. It is in that context that PRIME has developed, and grown remarkably, from small beginnings in the UK twenty years ago to a world-wide network of several hundred Christian medical educators sharing the same vision and mission today.

\section{PRIME's Mission}

PRIME is a global network of Christian healthcare professionals (Nurses, Doctors, Paramedics) involved in teaching their discipline. There are four major components of our mission:

- To support and improve medical education in resource-poor countries

- To demonstrate and teach compassionate person-centred medical practice

- To model the example of Jesus as the perfect physician and teacher

- To restore Christ's values to medical education and practice

All this is with the aim of restoring a Christian ethos to medical education worldwide and so improving health-care for all. It has wisely been said that, "A (medical) teacher. . . can influence the lives of many times more patients through his or her students. . than through a career of surgeries or clinics."13

PRIME is linked to the Christian Medical Fellowship (CMF), UK and the International Christian Medical and Dental Association (ICMDA). It responds to specific invitations for partnership from groups of doctors or other health professionals in developing and restructuring countries. It has also worked with groups of pastors in some countries, teaching them basic health care and encouraging them to see this as part of their church's ministry to the community. Its usual pattern of work is to make recurrent short-term (usually 1-3 week) visits to host countries with teams of 2 or 3 tutors to run teaching programmes and maintain relationships with hosts via email and Skype between visits. It provides teaching and training in person-centred and evidence-based medical practice for underresourced doctors from a Christian perspective and where possible, advises on local curriculum development, training methods, and health care 
management. PRIME's teaching is in the context of forming genuine relationships with our hosts (generally essential to work effectively in nonWestern cultures). It emphasizes the importance of a compassionate, whole person approach to patients, builds ethical frameworks for decision making, and includes a spiritual perspective on patient care. Its teaching is learner centred, interactive, and problem based (a patient-centred approach to medical practice needs to be taught using a learner-centred approach). ${ }^{14}$ It aims for sustainability by training medical teachers in good educational methodology whenever possible.

PRIME operates its courses with the approval of the University of Brighton and Sussex Department of Postgraduate Medicine and (where possible) host country university departments. It is staffed by volunteer Christian doctors and nurses with experience and qualifications in medical education, and runs a small office with a part-time manager and administrators. It produces educational materials to spread its vision (mostly electronic on CD's or online, but with some paper publications). It now has branches in Australia, Portugal, Kenya, and Nigeria that plan and run their own teaching programmes internationally and has specialised Mental Health and Palliative Care sections. Most of PRIME's teaching focuses on compassionate, holistic care, communication skills, professionalism and ethics sometimes structured around clinical topics. For example, there is a "Values Added" modular course aimed at junior doctors in the early years of their training (based on small groups looking at a DVD/CD and then discussing the questions raised with a more experienced facilitator/tutor) that aims to add a Christian perspective to their standard training and encouragement in its practical application to patient care and teaching.

PRIME has found that because all people are made in God's image, most respond positively to compassion and Godly values displayed in healthcare and its teaching. It has worked with Hindus, Muslims, Buddhists, Sikhs, and Atheists, but all agree about the core principles of good medical practice, and all can see that Jesus was an exemplary physician and teacher in his dealings with people. This enables PRIME to maintain and promote its Christian basis and values whilst being acceptable to people of all faiths and none. Participants are always asked to evaluate PRIME courses and sometimes follow-up studies are conducted a few months later to see if those who took part have sustained any change in practice as a result. Whilst it is very hard to measure this objectively, there have been numerous personal testimonies to the transforming nature of PRIME programmes such as, "Today I became a doctor," "Before this I wanted to leave (my country) to earn more money, now I want to stay and serve our people compassionately," "I now understand that all patients are human beings like me and will treat them accordingly," and "Now I know how to serve Jesus through practising medicine."

\section{An example - teaching whole person care in Kenya}

In 2002, three PRIME tutors (British GP educators, two of whom had worked in Kenya years previously) were invited to Kenya to facilitate the inaugural four-day conference of the Kenyan Association of Family Physicians (KAFP). Many of the members of this were Christians and also members of the Kenyan Christian Medical and Dental Association (CMDA). The programme was a values-based introduction to holistic care, good communication skills, professionalism, and various other topics; all taught interactively with an implicit (and sometimes explicit) Christian perspective. The tutors were invited back in 2003 to facilitate the second annual conference (one of the original team and another tutor with previous experience of working in Kenya went on this occasion). The programme for this visit focussed on chronic disease management and good practice organisation to provide holistic care and took place in two centres. Email contact with key Kenyan Christian medical leaders was maintained through the years (one ex-patriot Family Physician in particular), and in 2010, three other PRIME tutors ran a programme at the invitation of KAFP at a conference on empowering medical educational leadership. Then in 2014, one of the original PRIME 
team to visit Kenya was invited by the ex-patriot family physician in partnership with the leaders of the CMDA to formally launch PRIME in Kenya. The idea was to establish an indigenous PRIME Kenya, to spread the vision of faith-based, person-centred, holistic care throughout the country and wider to other East African countries through members of the CMDA teaching PRIME concepts and using PRIME materials. The core PRIME seminars on "Whole Person Care" and "Teaching to Change Hearts" were taught in a number of centres around the country, and in each place, key local doctors were identified who would be active in taking the vision forward. A Kenyan surgeon based in Nairobi became a very active and enthusiastic advocate and teacher of the PRIME vision around Kenya and in other East African countries, and other doctors with faculty positions in a new medical school were able to incorporate aspects of the PRIME material into the curriculum they were teaching. Thus over a twelve-year period, recurrent visits and maintained personal relationships between PRIME tutors and in-country colleagues led to the forming of a true partnership, with Kenyan partners eventually totally owning and running with the vision themselves in their own situations and more widely across East Africa.
To give an idea of PRIME's activity, in 2015, 115 international PRIME tutors carried out 76 separate programmes in 24 different countries in Africa, Asia, and Europe, providing 687 days of teaching (out of 1451 days in the host country) and training to nearly 4,500 individuals. At current standard NGO consultancy rates for teaching and subsistence, this would have cost $£ 535,000$. The actual cost (met by tutors) was $£ 31,850$. The fact that tutors give their time and expertise freely, adds powerfully to the Christian impact of the work. There is also the vast amount of work done in-country by national teachers and tutors who replicate the teaching and methods in their day-to-day work and teaching.

PRIME believes that this training will improve the care provided to the thousands of patients each of those individuals will treat, or the hundreds of healthcare students they will teach in the course of their careers.

So in summary, PRIME teaches and encourages healthcare professionals worldwide to teach and practice whole person medicine, using patient and learner-centred teaching methods. It promotes compassionate medicine using Jesus as a role model and seeks to use the basis of Christian values as a central platform for change wherever it's tutors work.

Any health-care professional committed to a compassionate, holistic approach to patient care is welcome to join the PRIME Network, and those involved in teaching who are able to give a week or two a year at their own expense are welcome to apply to be PRIME tutors (details and application forms from admin@ prime-interational.org.uk). In the next few months, PRIME is running training programmes in Australia, Kenya, Nigeria, Peru, and UK.

\section{References}

1. Crislip AT. From monastery to hospital: Christian monasticism \& the transformation of health care in late antiquity. Ann Arbor: University of Michigan Press; 2005. http://dx.doi.org/10.3998/mpub.93465

2. Pannenberg W. Christianity and the West: ambiguous past, Uncertain Future. First Things: Mon J Relig Publ Life. 1994;18. Available from: https://www.firstthings.com/article/1994/12/christi anity-and-the-westambiguous-past-uncertain-future

3. Hookyaas R. Religion and the rise of modern science. Edinburgh: Scottish Academic Press; 1972.

4. Hardiman D, editor. Healing bodies, saving souls: medical missions in Asia and Africa,

Wellcome Series in the History of Medicine, Clio Medica 80. Amsterdam and New York: Rodopi; 2006.

5. Israel JI. Radical enlightenment: philosophy and the making of modernity 1650-1750. Oxford: Oxford University Press; 2001.

6. Crick F. The astonishing hypothesis: the scientific search for the soul. London: Simon and Schuster; 1994.

7. Coulehan J. Viewpoint: today's professionalism: engaging the mind but not the heart. Acad Med. 2005;80: 892-8. 
http://dx.doi.org/10.1097/00001888-200510000$\underline{00004}$

8. Steinbeck B, London AJ, Aras JD. Ethical issues in modern medicine: contemporary readings in bioethics. Boston: McGraw-Hill; 2009.

9. Rechel B, McKee M. Health reform in central and Eastern Europe and the former Soviet Union. Lancet. 2009;374(9696):1186-95. http://dx.doi.org/10.1016/S0140-6736(09)61334-9

10. Chudi IP. Healthcare problems in developing countries. Med Practice Rev. 2010;1(1):9-11.

11. Rayner L, Easthope G. Postmodern consumption and alternative medications. J Sociol. $2011 ; 37$ (2) :157-76.

Http://dx.doi.org/10.1177/144078301128756274
12. World Health Organization. WHOQOL and spirituality, religiousness and personal beliefs: report on WHO consultation. Geneva: WHO; 1998. Available from: http://apps.who.int/iris/bitstream/10665/70897/1/W HO_MSA_MHP 98.2_eng.pdf

13. Smith BH, Edwards E, Murchie P. Society for academic primary care: scotching the myths. Br J Gen Prac. 2005;55:513 (316).

14. Stewart M. Patient-centered medicine: transforming the clinical method. Oxford: Radcliffe Publishing; 2003.

Peer Reviewed

Competing Interests: Dr. Morgan is a Staff Tutor and executive member of PRIME

Correspondence: Huw Morgan, United Kingdom. jhcmorgan@gmail.com

Cite this article as: Morgan H. PRIME Partnerships in International Medical Education Restoring a Christian ethos to medical education worldwide. Christian Journal for Global Health (Nov 2016), 3(2):134-139.

(C) Morgan H. This is an open-access article distributed under the terms of the Creative Commons Attribution License, which permits unrestricted use, distribution, and reproduction in any medium, provided the original author and source are properly cited. To view a copy of the license, visit http://creativecommons.org/licenses/by/4.0/

$$
\text { WWW.cjgh.org }
$$

